\title{
Community-owned rural water supplies in Galicia (Spain): supporting role in the groundwater self-management
}

\author{
Acacia Naves ${ }^{1}$ (D) Enrique José Varela-Álvarez ${ }^{2}$
}

Received: 4 July 2021 / Revised: 17 October 2021 / Accepted: 19 October 2021 / Published online: 25 October 2021

(c) The Author(s) 2021

\begin{abstract}
The community-owned rural water supplies in the rural areas of Galicia developed spontaneously in response to the historical shortcomings of local administrations, which are a clear example of commons management strategies. They have developed a water self-management model integrated into a complex network of actors. More than one-quarter of the total population rely on these systems. However, a large part of supplied water does not comply with the sanitary standards due to deficiencies in the system's design, operation, and maintenance and the water catchment protection. Furthermore, the owners face difficulties complying with basic legal requirements due to the complexity of the regulatory framework and the lack of training of the water board members. COXAPO ('Comunidad Xeral de Augas de Galicia'), an association of 150 community-owned water supplies, advises, trains, and supports the water boards for the legal, administrative, economic, and technical systems management. As a result, it gets the systems legally compliant concerning the institutional management and quality of supplied water. The success of this network governance recommends a role to the administration in promoting the networking of water boards by supporting the existing water supply associations and encouraging their constitution or provisioning equivalent services in regions where they do not exist.
\end{abstract}

Keywords Rural water supplies $\cdot$ Community-owned $\cdot$ Galicia $\cdot$ Governance $\cdot$ Hydrogeoethics

\section{Introduction}

The end of a global and local natural resource management cycle, which began with the significant development of drinking water management in the last quarter of the twentieth century, is occurring nowadays. The massive implementation of public policies and services within this stage has been related to implementing welfare models and aimed fundamentally at the vast urban population concentrations established around megacities and global metropolitan areas. In this context, the rural environment and its former population settlements have been losing demographic weight in the overall population of states.

In the case of Europe, this phenomenon of urbanisation and global metropolitanization (Brenner 1999) presents a

Acacia Naves

acacia.naves@udc.es

1 Civil Engineering School, International Center of Advance Research (CICA), University of Coruña, A Coruña, Spain

2 Faculty of Public Management, Governance Observatory G3, University of Vigo, Vigo, Spain distinctive feature: In 2018, 39.3\% of the population lived in the cities, $31.6 \%$ lived in towns and suburbs, and $29.1 \%$ lived in rural areas (EUROSTAT 2020); and some rural and urban territorial structures are maintained ("urban-rural continuum", EUROSTAT 2021) in which elders continue to live with increasing problems of access to services and in situations of vulnerability and poverty (European Commission 2021; Kiss 2021).

The European diversity and the different models of welfare democracy have allowed rural people to continue to live in their environments and maintain a range of governance and common management strategies. The management of natural resources in those rural environments has been the subject of analysis by numerous studies of the commons, including those of "common-pool resources" models by Ostrom $(1990,2001)$ and Poteete et al. (2010). Water management has always been of enormous relevance in these studies, as it is essential for population fixation, outflow, or "expulsion" (Sassen 2014). The cooperatives in the water sector, which are generically referred to as "community-owned rural water supplies", are a clear example of a new model of water governance (Huitema et al. 2009) 
and remaining common self-management in rural environments in Europe (OECD 2011). This phenomenon is particularly relevant in Spain (e.g., Fornés et al. 2005; Romay and Gañete 2007; Costejà 2009; Bukowski 2011).

The technical and economic feasibility of centralised infrastructures in rural areas of Galicia, a Spanish region located in the northwestern corner of the Iberian Peninsula (Fig. 1), is severely limited by the distance from rural to highly populated areas, the wide dispersion of population, and the significant required investments to undertake them. Local people have developed spontaneously autonomous water supply systems in response to the historical shortcomings of local administrations. They consist of private wells and small rural supplies which collect water from springs and supply one or several houses. According to Romay and Gañete (2007), more than one-quarter of the total population rely on groundwater through autonomous-traditional solutions in the watersheds of Galicia. Furthermore, some people refuse the connection to an available centralised supply system or combine both systems due to the lower price of water in the traditional systems. The research performed within the framework of the LIFE Aqua-plan project (ECCINEA 2021a) and LIFE Rural supplies project (EC-CINEA 2021b), founded by EU, shows that in Abegondo municipality, a rural area in Galicia, only $40 \%$ of the homes have a connection to the municipal system. However, it is available for $90 \%$ of homes (Naves et al. 2021a,b). Moreover, a part of connected homes uses water from the centralised municipal system to complement the water from the wells and those small rural supplies.

Users are responsible for infrastructure construction, operation, maintenance, supplied water quality, and legal and administrative requirements in the small rural water supplies. Users' cooperatives are constituted for the construction and management of the systems, except for the individual or very small ones. They have developed a water self-management model based on traditional rural governance and commons management strategies, contributing to environmental, social, and territorial sustainability. However, these communities are integrated into a complex network of actors in which the national, regional, local, and basin district administrations participate and productive sectors and neighbours are also included (Naves et al. 2021a,b), defining multi-level governance (Ostrom 2010) and hybrid management (Christensen and Lægreid 2011).

This work reviews the main governance and self-management problems of the community-owned rural water supply in Galicia, based on the results of several previous research. It then shows how the role played by COXAPO, an association of water systems that advises and supports the selfmanagement of its members. The success of COXAPO's network governance shows how a simple support structure can overcome most of the identified problems. From a geoethics point of view, it is interesting to address whether it is possible to establish such a support infrastructure on a widespread basis in the region and who should be responsible for

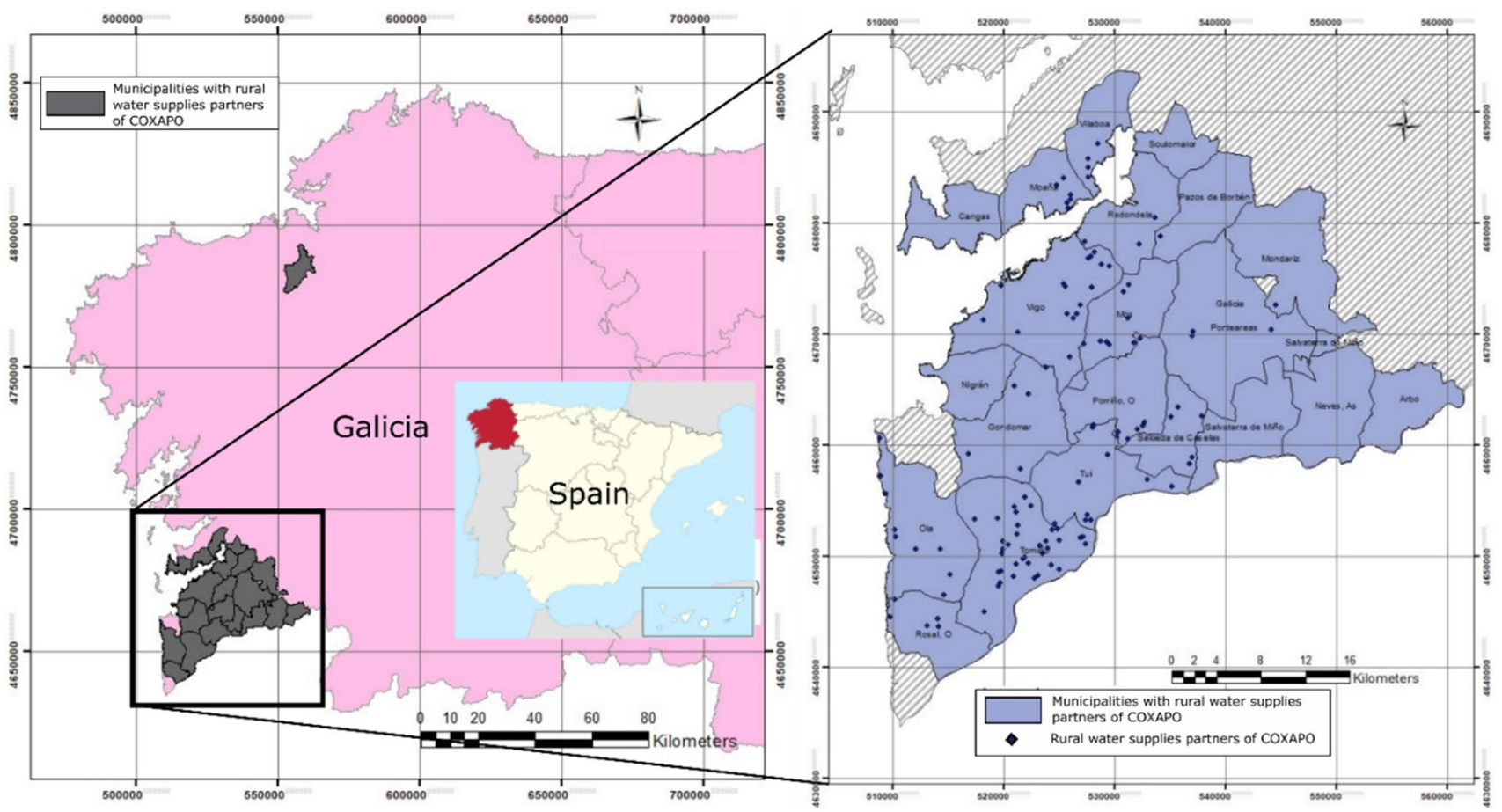

Fig. 1 Location of Galicia and the community-owned water supplies partners of COXAPO 
implementing it. That approach is based on the developing concept of hydrogeoethics aimed at ethics and best practices related to responsible groundwater science and engineering management and interrelated dimensions such as environmental law, social sciences, and cultural and traditional values (details in Abrunhosa et al. 2021).

\section{Methodology}

This study analyzes the community-owned rural water supply in Galicia based on the scarce literature and several previous research projects. This analysis is approached first from the point of view of resource availability, including the estimated effect of climate change. Next, the quality issues of the water supplied by these systems are assessed following the regulations for human consumption. Finally, the difficulties encountered by system managers in carrying out the mandatory administrative procedures and complying with the complex regulatory framework are presented.

Afterwards, COXAPO, an association of communityowned water supplies, is described, and its role in the governance and management of the 150 associated supply systems is assessed. The research is based on the technical documents provided by the managers of COXAPO and interviews with the COXAPO's technicians and with water boards of most of the systems. The documentation includes the registration and deregistration book, and reports on the structure of the association and management protocols. Several meetings were held with COXAPO managers and technicians during 2020 to discuss the organisation of the association and the main identified governance problems. Information was provided on the different systems, such as the description of the infrastructure, the mechanisms for monitoring the supplied water volume and the quality of the water, incidences of poor water quality, etc. This information was cross-checked and complemented by interviews with water boards of most associated systems performed between January and July 2020. Finally, the advantages of the networked water governance approach proposed by COXAPO and the administration's role in this multi-level governance scheme are discussed.

\section{Context: the reality of the rural water supplies in Galicia}

The community-owned rural water supplies in Galicia have not been deeply analyzed as a whole. However, studies have been carried out in some areas that allow general conclusions to be drawn. For example, the autonomous rural water supplies in the south of Abegondo municipality, located in the study area, were studied in depth within the LIFE Rural
Supplies project (Ameijenda 2017; Samper et al. 2021), aiming to identify their main threats to strengthen their sustainability. Derived conclusions are consistent with those from other research in the study area related to groundwater management (Naves et al. 2021a,b) or the impact of civil engineering works in groundwater (Li 2012; Samper et al. 2019).

\subsection{Groundwater resources}

The granitic and metamorphic rocks that dominate the study area have traditionally been considered almost impervious or very low permeability. Therefore, their groundwater resources have usually been neglected in planning and water management (Raposo et al. 2012). However, the traditional use of shallow groundwater proves that the weathered and fractured rock stores significant water volume that should not be neglected in the water resources evaluation. Furthermore, a few studios of groundwater resources in this region estimate the recharge to be between 8 and $20 \%$ of the precipitation rate (900-2500 $\mathrm{mm}_{\text {year }}{ }^{-1}$ ) (Soriano and Samper 2000; Xunta de Galicia 2015; Raposo et al. 2012; Naves et al. 2021a,b; Samper et al. 2021). Thus, the problems of guaranteed supply observed in some water supplies are generally more related to infrastructure design and management deficiencies than the availability of resources.

According to Samper et al. (2021) and Raposo et al. (2013), the expected effects of climate change in a watershed of the study area at the end of the twenty-first century include a decrease in groundwater resources (6-12\%), a possible slight decline in the water table, and a concentration of recharge in shorter periods. Consequently, the reduction of groundwater resources should not affect their availability to meet demand. However, supply problems could arise in some systems that draw water from springs due to the decline of the water table by a few meters in periods of drought. Those problems could be overcome by deepening the water catchments or drilling wells.

\subsection{Water quality}

There is a concern about drinking water's chemical and microbiological quality in the community-owned rural water supplies due to the owners' lack of proper water quality control. Users assume that the water is of good quality, because it has been consumed traditionally. In many cases, they do not even carry out the mandatory physico-chemical, bacteriological, and radiological analyses established by the regulations.

Nevertheless, reliable water quality data from previous projects are available for the study area (Ameijenda 2017; Li 2012; Naves et al. 2019, 2021b; Samper et al. 2019, 2021 and references therein) obtained in the last years from appropriate monitoring of COXAPO-associated rural supplies. 
Unfortunately, data compiled by COXAPO cannot be published due to legal data protection reasons, but the conclusions derived by its technicians coincide with those previously published (COXAPO, personal communication).

Many water catchments do not comply with the sanitary standards of supply water due to bacteriological contamination (Ameijenda 2017; Naves et al. 2019; Samper et al. 2021). This situation is due to shortcomings in Naves et al. (2019): (1) infrastructure design; (2) system maintenance; and (3) territorial planning to take into account the protection of water catchments. To prevent this pollution requires proper design, maintenance and cleaning of the water catchments, the reservoirs, and the network. In addition, bacteriological contamination can be eliminated by chlorinating the water in any case. However, many community-owned water supplies lack a chlorination system, or it is not used correctly.

Some water catchments located in areas with significant agricultural or livestock pressure have shown nitrate pollution as a consequence of the poor management of the manure in the fields, the discharge of slurry from farms, and the inadequate planning of land use, which does not account for groundwater protection (Naves et al. 2019; Samper et al. 2021).

Finally, the concentrations of some metals, especially alumina and manganese, exceed the permissible limits for drinking water at some points of the study area (Naves et al. 2021a,b; Samper et al. 2021). Those high concentrations are related to suspended matter in most cases, and, therefore, the pollution can be prevented by simply filtration of groundwater. However, many systems do not account for a proper filtration system.

\subsection{Legal and administrative issues}

User communities face difficulties in complying with basic legal requirements for the management of a water supply system. They are challenged with a complex multi-level regulatory framework that includes European directives, national, regional, and municipal laws and regulations. In some cases, the water boards are unaware of or not clear about the conditions to be met by the supply system (i.e., obligation to install chlorination) and the administrative procedures they have to go through (i.e., register of the water catchments) to comply with the legal framework. Moreover, the members of the water boards are often not trained to understand the regulations or to carry out these administrative procedures, which must be done telematically. This is especially true for user communities with a few dwellings and neighbours or located in clearly rural environments due to social and demographic conditioning factors.
In other cases, the water boards decide not to register or legalise a supply system. This is because it involves some obligations (i.e., supplied water quality monitoring), and they do not perceive any advantage. Thus, those systems do not exist from the administration's point of view and are not monitored or sanctioned.

Nowadays, any water catchment in Spain legally requires a river basin district administration, including its register. However, most of the rural water catchments in Galicia are not registered. It is estimated that less than $30 \%$ of existing wells and spring catchment of rural supplies have been registered (Naves et al. 2021a,b).

The registration of any water supply system in the National Information System of Drinking Water (SINAC) is also mandatory. It requires forming a water board following the regulations, establishing a sanitary protocol of the supply system, and monitoring the supplied water volume and quality. Unfortunately, only a few of the community-owned water supplies in Galicia are included in this register and, therefore, legally compliant.

\section{COXAPO, a community-owned water supplies association}

COXAPO ('Comunidad Xeral de Augas de Galicia') is an association of community-owned water supplies which advises and supports its partners' self-management. It is a formal institution that contributes to improving the governance of the supply systems and the water management of its communities.

The origin of COXAPO is on the community-owned water supply built and set up in operation in the $70 \mathrm{~s}$ of the twentieth century in the village of Estás (Tomiño) in the southwest of Galicia. This experience and others of business nature of the board members generated knowledge for informal advising other systems on water use, water quality monitoring, and administrative and legal issues. Since 2006, communities of users have worked together in an association that helps them manage their water supply systems. Figure 2 shows the time evolution of the number of partners of COXAPO. The association grew sharply from 2010 as it became known throughout Galicia by acting as an interlocutor with the administration, representing the private rural supply systems in opposition to implementing a new tax.

Nowadays, 150 community-owned water supply systems in Galicia are members of COXAPO, which provide service to nearly 70,000 inhabitants, distributed among 19,600 homes (Data related to March 2020). Figure 1 shows the location of the community-owned rural water supplies, which are partners of COXAPO. Services are provided to community-owned water supplies in different territorial contexts, ranging from neighbourhoods in the suburbs of a 


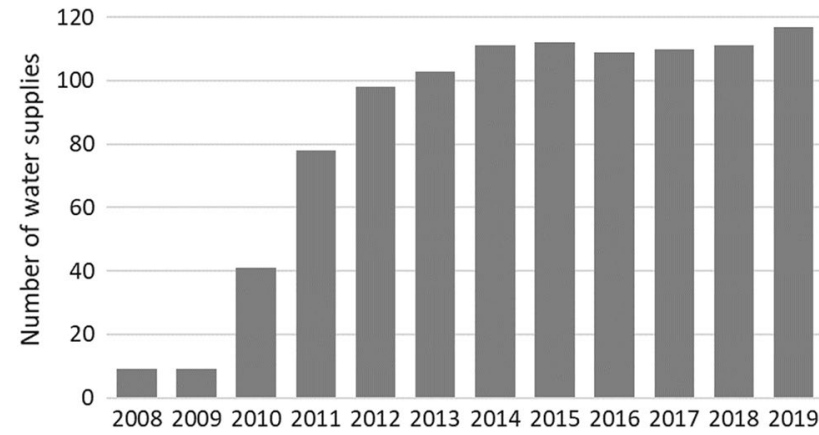

Fig. 2 Time evolution of the number of the community-owned water supplies partners of COXAPO

large city such as Vigo (296,692 inhabitants; INE 2021) to rural communities. These contexts are socially and demographically conditioning for the population served and the water boards. Most of them are located in the southwest of Galicia, while some are north of the region. This implies differences in climate and natural environment. Furthermore, they are spread over 25 municipalities, and there are distributed between two different river basin districts (Fig. 3): Galicia-Costa and Miño-Sil river basin districts, having different structure and hydrological planning (Augas de Galicia 2015; Confederación HIdrográfica del Miño-Sil 2015). This involves a context of institutional complexity.
On the other hand, the associated communities of users have an enormous variability and asymmetry in the number of users (supply units or homes). Figure 4 presents the distribution of sizes of the water supplies. The average size of the community-owned water supplies is $\sim 130$ users, but it ranges from a minimum of 6 users to 1100 users.

COXAPO has defined a common network governance system and institutional management for all user communities, regardless of complexity and diversity. It includes a dual dimension, socio-institutional, and organisational, reflected in the association's organisation chart (Fig. 5). The socioinstitutional dimension articulates a system of collective decision-making that complies with Spanish regulations on associations. The organisational dimension accounts for a technical office that works with the boards of the user communities. It provides support for the legal, administrative, economic, and technical management of the systems.

The technical office guides each user community in its constitution as an association, drafting its statutes and registration in the SINAC. It analyzes each supply system and proposes the necessary improvements to comply with current legislation and, above all, to supply water with health guarantees. These improvements mainly include: (1) drafting the authorisation for water abstraction from the river basin district; (2) improvements in the design of the water catchments, reservoirs, and network including the use of appropriate materials and signalisation; (3) the installation
Fig. 3 River basin districts in Galicia ( Modified from Augas de Galicia 2019)

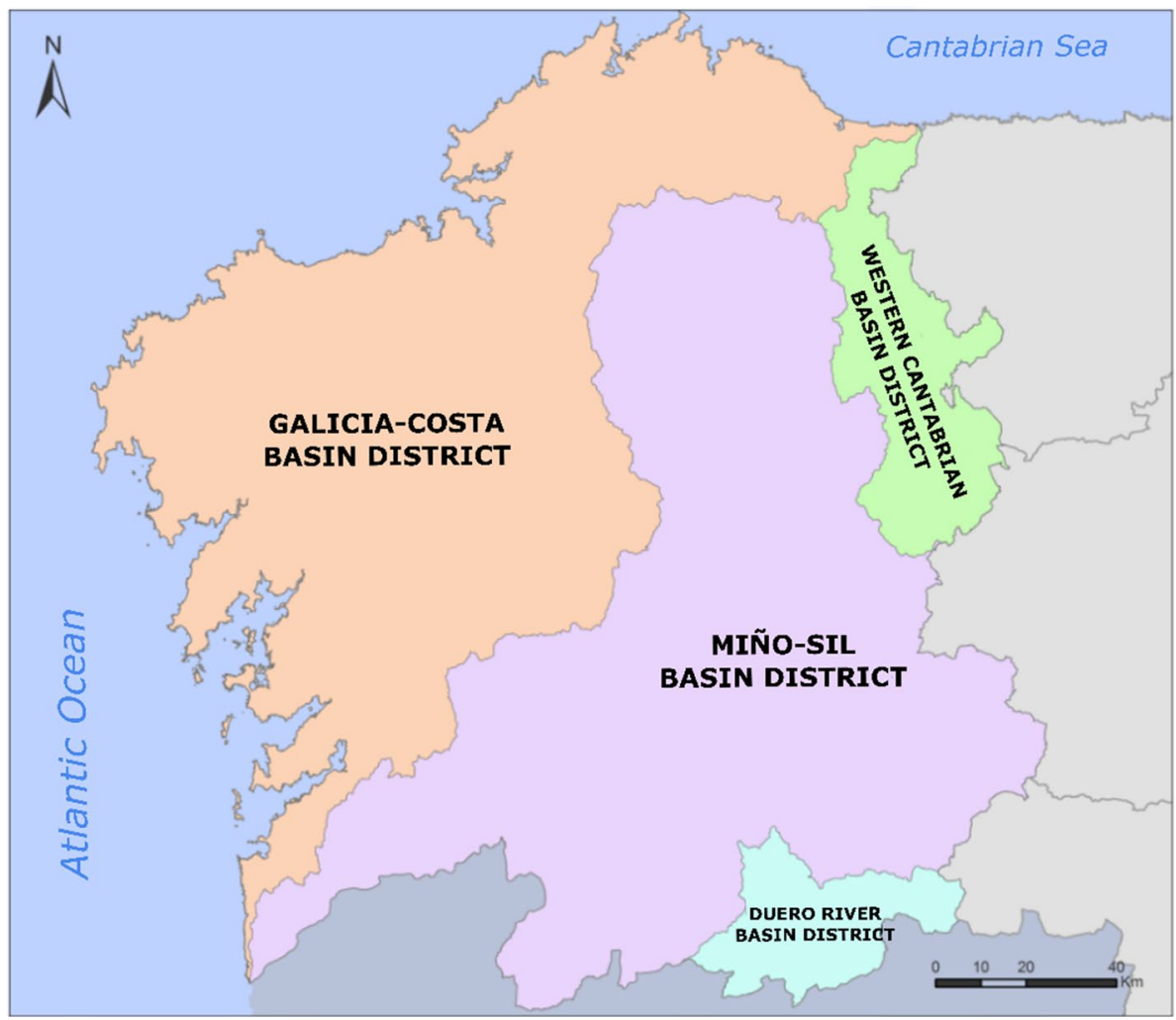




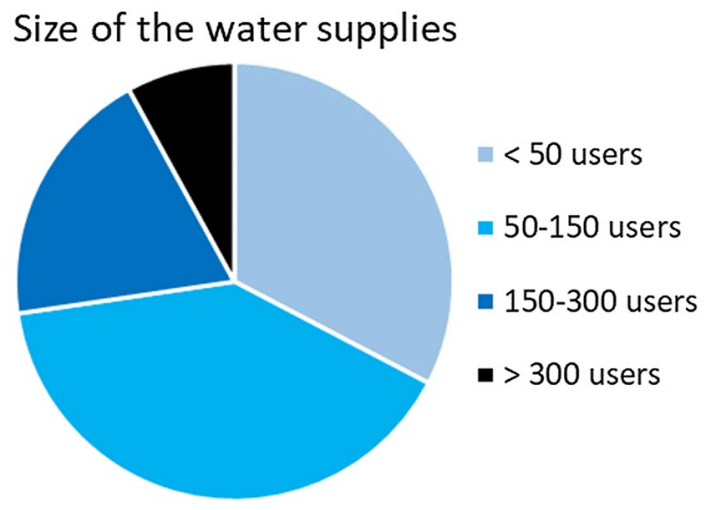

Fig. 4 Size of the community-owned water supplies partners of COXAPO

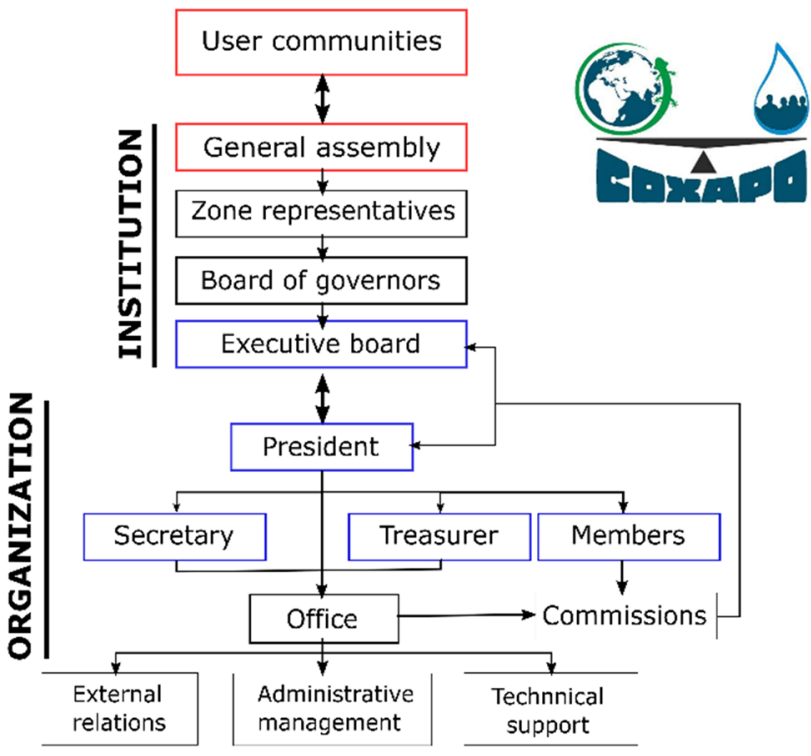

Fig. 5 Organisation chart of the COXAPO association

of an adequate filtering and chlorination systems; and (4) the placement of a general water meter. Then, each water board works together with the water office to develop a document that contains: (1) a detailed description of the system; (2) the protocols for its operation, maintenance, and cleaning; and (3) the identification of potential risks of system failure or water pollution and the foreseen measures in case they take place. Notice that the compliance of the operation, maintenance, and cleaning protocols include the good condition of the infrastructure and to keep up to the day the compulsory registrations of supplied flowrate, water quality analyses, chlorination system operation, control and registration of catchments and reservoirs, reservoir and network cleaning, and system incidents.

On a day-to-day basis, COXAPO trains, advises, and supports the water boards in the economic and administrative management, carrying out legal procedures, and complying with the protocols for the operation and maintenance of the network. As a result, on one hand, the diverse communityowned water supplies within COXAPO comply with all the current legislation and, on the other hand, they are capable of self-manage drinking water with sanitary guarantees through a proper design and maintenance of the supply system and the protection of the water catchments.

\section{Results and discussion}

Despite the global phenomenon of urbanisation and metropolitanization, people in the rural areas of Europe continue to live in their environments and maintain a range of governance and commons management strategies. For example, the community-owned rural water supplies in the rural areas of Galicia developed spontaneously in response to the historical shortcomings of local administrations, which are a clear example of that. They have developed a water self-management model integrated into a complex network of actors. The national, regional, local, and basin district administrations participate, and productive sectors and neighbours are also included. More than one-quarter of the total population relies on these autonomous-traditional solutions in the region.

Galicia is not a unique case. Local-scale water supplies are the backbone of water supply in the entire European region (WHO 2011). About 109 million people are estimated to be served by small water supplies representing $22 \%$ of the EU population, which is by no means negligible (Hulsmann and Smeets 2011). However, an urgent lack of reliable information on such supplies, the number of people served, and where they prevail. For example, around 3\% of the total population in Scotland is served by more than 17,000 private small rural water supplies (DWQR 2021; WHO 2011; Scottish Water 2021). The percentage increases to $6 \%$ of the total population in Ireland (Irish government 2020). In the federal states of Bavaria and Baden-Württemberg in Germany, more than one-third of the population is served by small public supplies (WHO 2011).

The analysis of the community-owned rural water supplies in some areas of Galicia showed deficiencies in the system design, operation, and maintenance and in the water catchment protection that results in water quality problems. A large part of supplied water does not comply with the sanitary standards due to bacteriological contamination and, in some cases, to high concentrations of nitrates and some metals. Furthermore, there is no water quality monitoring in many of those systems, since owners are the only ones responsible for it. They assume that the water quality is good, because it has been traditionally consumed. This 
situation poses a public health problem that needs to be addressed.

Hulsmann and Smeets (2011) stated that European authorities lack information on the occurrence and monitoring of small water supplies and the water quality they supply. They also concluded that EU-wide, not more than $60 \%$ of the smaller water supplies deliver water that is compliant with the requirements of the EU Drinking Water Directive 98/83/EC, according to the results of the WEKNOW study (Hulsmann and Smeets 2005) and of that performed in 2008 by DGENV European Commission (not available). The identified water quality problems were: (1) microbiological contamination; (2) man-made pollution such as nitrate and pesticides; (3) naturally occurring constituents of geological nature such as arsenic, iron, manganese, and sulphate; and (4) organoleptic parameters such as colour, taste, odour, and turbidity. These conclusions are consistent with those obtained for Galicia.

Therefore, the questions are: who is responsible for addressing the problem of water quality in the communityowned rural water supplies in Galicia, and how could it be solved?

According to the law, the administration provides all residents with a water supply suitable for human consumption. However, since the construction and management of centralised supply systems in rural areas are not sustainable, the administration should improve the small autonomous rural supply systems, incorporating a filter and a chlorination system, establishing protection measures in the catchment areas and monitoring water quality of the groundwater. In this respect, the legislation and regulations already require water treatment and monitoring of the condition of installations and water quality to the owners of the communityowned rural water supplies.

However, the legal framework requirements are challenging to meet due to the actual conditions of the communityowned rural water supplies. On one hand, it is due to the complexity of the regulatory framework with different levels of administration (national, regional, municipal, and river basin districts). As a result, the water boards are unclear about all the administrative procedures they have to carry out or all the regulations they must comply with. On the other hand, the members of the water boards are volunteers and, in general, do not have sufficient technical, legal, and administrative training in water management. As a result, the water boards are not able to properly manage their systems. There is also no possibility to outsource the management due to financial constraints.

Besides, the administration cannot demand a quality of service from the neighbours trying to overcome a deficiency in their functions. An appropriate solution to this problem must therefore share the responsibility between the administration and the water boards.
The analyses of the role played by COXAPO in its partners have shown that the association gave advice and support to the water boards to ensure compliance with the regulations and their capacity to self-manage drinking water with sanitary guarantees. It has not been possible to find any welldocumented cases of other European associations of community-owned rural water supplies, except for the National Federation of Group Water Schemes (NFGWS) in Ireland. The NFGWS is an association of over 400 Irish communityowned water supplies serving more than 65,000 households (Brady and Gray 2010). It provides guidance and support to partner water boards, and leads programs on water quality assurance, water board capacity building, water education, water resources, and environmental protection (NFGWS 2021). Furthermore, it represents all the community-owned rural water supplies as a partner in hydrological planning and the analysis of administration regulatory proposals.

The success of the network governance model conducted by COXAPO in Galicia and NFGWS in Ireland shows the desirability of an entity playing a similar role in the guidance and support of water boards. With the intention that the systems and the administration share the responsibility for providing quality water supply, the administration should support these entities where they exist and encourage their constitution in regions where they do not exist.

\section{Conclusions}

More than one-quarter of the total population rely on community-owned rural water supplies in the rural areas of Galicia. The available groundwater resources allow the demand of the systems to be met, even taking into account the estimated effects of climate change. This system's possible lack of security of supply is generally more related to infrastructure design and management deficiencies than resources availability. A large part of supplied water does not comply with the sanitary standards due to bacteriological contamination and, in some cases, to high concentrations of nitrates and some metals. Bacteriological contamination is a consequence of deficiencies in the system design, operation, and maintenance and in the water catchment protection. Nitrate pollution is observed in areas with significant agricultural or livestock pressure due to the poor management of the manure in the fields, the discharge of slurry from farms, and inadequate land-use planning. Finally, the concentration of some metals which exceed the permissible limits for drinking water at some points is of natural origin. Besides, user communities face difficulties complying with basic legal requirements for managing a water supply system due to the complexity of the regulatory framework and the fact that the members of the water boards are not trained to understand the regulations or carry out administrative duties 
procedures. The importance of systems in Galicia's rural areas and their main problems and challenges coincide with those reported for other rural areas in Europe.

The 150 community-owned water supplies associated with COXAPO have defined a common network governance system and institutional management for all user communities, regardless of complexity and diversity. They are aware and concerned about the need to supply water that meets the quality standards for human consumption and preserve water resources' quality. They are informed of the conditions to be met by the supply systems and the administrative procedures they have to go through to maintain the self-management of drinking water with sanitary guarantees and comply with the legal framework. Furthermore, they account for a technical office that trains, advises, and supports the water boards for legal, administrative, economic, and technical management systems. As a result, all these water supply systems are legally compliant regarding institutional management and the quality of supplied water.

The success of the network governance model conducted by COXAPO in Galicia and also by NFGWS in Ireland seems to recommend to the administration a role in promoting the networking of water boards, the strengthening of the existing community-owned water supplies associations and the provision of information, training, and support services to the water boards where this kind of associations do not exist. Support to water boards is expected to result in increased compliance with legal requirements and, as a consequence, improved systems and quality of the water supplied.

Acknowledgements This work has been performed within the framework of the contract "COXAPO Water governance in the 2030 agenda" (IN-0047-20, UVIGO) founded by COXAPO. This work could not have been performed without the collaboration of the COXAPO executive board, technicians, and the members of the water boards of the associated water supply systems. We thank the comments and corrections of the two anonymous reviewers and the suggestions of H.I. Chaminé, because they contributed to improve the manuscript.

Funding Open Access funding provided thanks to the CRUE-CSIC agreement with Springer Nature.

\section{Declarations}

Conflict of interest On behalf of all authors, the corresponding author states that there is no conflict of interest.

Open Access This article is licensed under a Creative Commons Attribution 4.0 International License, which permits use, sharing, adaptation, distribution and reproduction in any medium or format, as long as you give appropriate credit to the original author(s) and the source, provide a link to the Creative Commons licence, and indicate if changes were made. The images or other third party material in this article are included in the article's Creative Commons licence, unless indicated otherwise in a credit line to the material. If material is not included in the article's Creative Commons licence and your intended use is not permitted by statutory regulation or exceeds the permitted use, you will need to obtain permission directly from the copyright holder. To view a copy of this licence, visit http://creativecommons.org/licenses/by/4.0/.

\section{References}

Abrunhosa M, Chambel A, Peppoloni S, Chaminé HI (2021) PrefaceAdvances in geoethics and groundwater management: theory and practice for a sustainable development. In: Proceedings of the 1st congress on geoethics and groundwater management, Porto, Portugal 2020. Adv Sci Technol Innov Series. Springer, Cham, pp xxi-xxvi

Ameijenda C (2017) Life rural supplies: sustainable solutions for very small water supplies (LIFE12 ENV/ES/000557) https://ec.europa. eu/environment/life/project/Projects/index.cfm?fuseaction= search.dspPage\&n_proj_id=4685. Accessed 29 Jun 2021

Augas de Galicia (2015) Hydrological planning of the Galicia-Costa river basin district (2015-2021) RD 11/2016 [In Galician]. https:// augasdegalicia.xunta.gal/seccion-tema/c/Planificacion hidro loxica?content=/Portal-Web/Contidos_Augas_Galicia/Secci ons/plan-hidroloxico-gc/seccion.html\&sub=Subseccion_002/. Accessed: 29 Sep 2021

Augas de Galicia (2019) Gestión de inundaciones en Galicia-Costa. Proyecto Hazrunoff. http://www.hazrunoff.eu/wp-content/uploa ds/2019/04/Augas_de_Galicia.pdf. Accessed 29 Jun 2021

Brady J, Gray NF (2010) Group water schemes in Ireland: their role within the Irish water sector. Eur Water 29:39-58

Brenner N (1999) Globalisation as reterritorialisation: the re-scaling of urban governance in the European Union. Urban Stud 36(3):431-451

Bukowski JJ (2011) Sharing water on the Iberian Peninsula : a Europeanisation approach to explaining transboundary cooperation. Water Alternativ 4(2):171-196

Christensen T, Lægreid P (2011) Complexity and hybrid public administration-theoretical and empirical challenges. Public Org Rev 11(4):407-423

Confederación HIdrográfica del Miño-Sil (2015) Hydrological planning of the Miño-Sil river basin district (2016-2021) R.D. 1/2016 [In Spanish]. https://www.chminosil.es/es/chms/planificacionhi drologica/plan-hidrologico-2015-2021-vigente-rd-1-2016. Accessed 29 Sep 2021

Costejà M (2009) Adaptabilidad institucional: dinámicas en la evolución de los sistemas socio-ecológicos de uso del agua en España. Universidad Autónoma de Barcelona, Barcelona. (PhD Thesis)

DWQR (2021) Private water supplies. drinking water quality regulator for Scotland. https://dwqr.scot/private-supply/. Accessed 29 Sep 2021

EC-CINEA (2021a) Integrated management of water resources and their application to the local planning of the SCI AbegondoCecebre, AQUA-PLANN PROJECT, Reference: LIFE07 ENV/E/000826 LIFE. https://webgate.ec.europa.eu/life/publi cWebsite/project/details/2815. Accessed 06 May 2021

EC-CINEA (2021b) Sustainable solutions for very small water supplies, LIFE RURAL SUPPLIES, Reference: LIFE12 ENV/ ES/000557. https://webgate.ec.europa.eu/life/publicWebsite/proje ct/details/3860. Accessed 06 May 2021

European Commission (2021) Green paper on ageing. Fostering solidarity and responsibility between generations. https://ec.europa. eu/info/sites/default/files/1_en_act_part1_v8_0.pdf. Accessed 29 Jun 2021

EUROSTAT (2020) Urban and rural living in the EU. https://ec.europa. eu/eurostat/web/products-eurostat-news/-/edn-20200207-1. Accessed 29 Jun 2021 
EUROSTAT (2021) Applying the Degree of Urbanisation. A methodological manual to define cities, towns and rural areas for international comparisons (2021 edition). https://ec.europa.eu/eurostat/ documents/10186/11395216/DEGURBA-manual.pdf/3a6bab6a3fb1-4261-ad5b-e604cb67dc0d. Accessed 29 Jun 2021

Fornés JM, de la Hera A, Llamas MR (2005) The silent revolution in groundwater intensive use and its influence in Spain. Water Policy 7:253-268

Huitema D, Mostert E, Egas W, Moellenkamp S, Pahl-Wostl C, Yalcin R (2009) Adaptive water governance: assessing the institutional prescriptions of adaptive (co-) management from a governance perspective and defining a research agenda. Ecol Soc 14(1):1-21

Hulsmann A, Smeets P (2005) Small systems, large problems: A European inventory of small water systems and associated problems. WEKNOW Web-based European Knowledge Network on Water. https://www.oieau.org/eaudoc/system/files/documents/41/208128/ 208128_doc.pdd. Accessed 28 Sep 2021

Hulsmann A, Smeets P (2011) Towards a guidance document for the implementation of a risk assessment for small water supplies in the European Union: Overview of best practices. DGENV European Commission (2011). https://ec.europa.eu/environment/water/ water-drink/small_supplies_en.html. Accessed 28 Sep 2021

INE (2021) Cifras oficiales de población resultantes de la revisión del Padrón municipal a 1 de enero. Instituto Nacional de Estadística. https://www.ine.es/dynt3/inebase/es/index.htm?padre=517\&capsel $=525$. Accessed 29 Jun 2021

Irish government (2020) Group water schemes and rural water issues. Department of Housing, Local Government and Heritage of Irish Government. https://www.gov.ie/en/publication/a524a-groupwater-schemes-and-rural-water-issues/. Accessed 28 Sep 2021

Kiss M (2021) Demographic Outlook for the European Union 2021. European Parliamentary Research Service. https://www.europ arl.europa.eu/thinktank/en/document.html?reference=EPRS_ STU(2021)690528. Accessed 29 Jun 2021

Li Y (2012) Hydrodynamic and geochemical models for environmental applications in civil and mining engineering. In: University of A Coruña, Coruña. (PhD Thesis)

Naves A, Samper J, Mon A, Pisani B, Fernandez J, Carvalho JM (2019) Demonstrative actions on water quality restoration and protection of spring catchments for rural water supply at Abegondo (Galicia, Spain). Sustain Water Resourc Manage 5:175-186. https://doi.org/ 10.1007/s40899-017-0169-5

Naves A, Samper J, Pisani B, Mon A, Dafonte J, Montenegro L, GarcíaTomillo A (2021b) Hydrogeology and groundwater management in a coastal granitic area with steep slopes in Galicia (Spain). Hydrogeol J. https://doi.org/10.1007/s10040-021-02349-5

Naves A, Samper J, Pisani B (2021a) Rural water supplies in Galicia. In: Abrunhosa M, Chambel A, Peppoloni S, Chaminé HI (eds) Advances in geoethics and groundwater management: theory and practice for a sustainable development. Advances in Science, Technology \& Innovation. Springer, Cham, pp 137-140

NFGWS (2021) National Federation of Group Water Schemes website, https://nfgws.ie/. Accessed 29 Sep 2021

OECD (2011) Water governance in OECD countries: a multi-level approach. OECD Publishing. https://doi.org/10.1787/9789264119 284-en. Accessed 29 Sep 2021

Ostrom E (1990) Governing the commons: the evolution of institutions for collective action. Cambridge University Press, Cambridge

Ostrom E (2001) Reformulating the commons. In: Burger J, Ostrom E, Norgaard R, Policansky D, Goldstein B (eds) Protecting the commons: a framework for resource management in the Americas. Island Press, Washington DC, pp 17-41

Ostrom E (2010) Beyond markets and states: polycentric governance of complex economic systems. Am Econ Rev 100:1-33

Poteete AR, Janssen MA, Ostrom E (2010) Working together: collective action, the commons, and multiple methods in practice. Princeton University Press, Princeton

Raposo JR, Molinero J, Dafonte J (2012) Parameterisation and quantification of recharge in crystalline fractured bedrocks in GaliciaCosta (NW Spain). Hydrol Earth Syst Sci 16:1667-1683. https:// doi.org/10.5194/hess-16-1667-2012

Raposo J, Dafonte J, Molinero J (2013) Assessing the impact of future climate change on groundwater recharge in GaliciaCosta, Spain. Hydrogeol J 21:459-479. https://doi.org/10.1007/ s10040-012-0922-7

Romay D, Gañete M (2007) The water user communities as an example of self-sufficiency in Galicia-Costa. In: Molinero J, Ortuño F, Valverde M, Lambán LJ (eds) Las aguas subterráneas en España ante las directivas europeas: retos y perspectivas. IGME, Madrid, pp 239-245 ([in Spanish])

Samper J, Naves A, Pisani B, Dafonte J, Montenegro L, García-Tomillo A (2021) Sustainability of groundwater resources of weathered and fractured schists in the rural areas of Abegondo (Galicia, Spain). Environ Earth Sci. https://doi.org/10.21203/rs.3.rs438348/v1

Samper J, Naves A, Mon A, Fernández L, Calvo J (2019) Conceptual and numerical groundwater flow models to evaluate construction, geotechnical and environmental effects of the Brión railway tunnel for the Ferrol Outer harbor. In: 46th IAH Congress Málaga 2019, Groundwater management and governance, coping with scarcity, 22-27 Septiembre 2019, Málaga (España)

Sassen S (2014) Expulsions: brutality and complexity in the global economy. The Belknap Press of Harvard University Press, Cambridge

Scottish Water (2021) Private water supplies. https://www.scottishwa ter.co.uk/your-home/your-water/private-water-supplies. Accessed 29 Sep 2021

Soriano G, Samper J (2000) Hydrogeology of a small pilot basin on granitic terrain: Valiñas basin (A Coruña) [in Spanish]. In: Molinero J, Ortuño F, Valverde M, Lambán LJ (eds) Las aguas subterráneas en España ante las directivas europeas: retos y perspectivas. IGME, Madrid, pp 73-82

WHO (2011) Small-scale water supplies in the pan-European region: background, challenges, improvements. World Health Organization, Regional Office for Europe. https://www.euro.who.int/_ data/assets/pdf_file/0018/140355/e94968.pdf. Accessed 27 Sep 2021

Xunta de Galicia (2015) Hydrological plan of Galicia-Costa [in Galician] https://augasdegalicia.xunta.gal/seccion-tema/c/Planificac ion_hidroloxica?content=plan-hidroloxico-gc/seccion.html\& sub=Subseccion_002/. Accessed 29 Sep 2021

Publisher's Note Springer Nature remains neutral with regard to jurisdictional claims in published maps and institutional affiliations. 